\title{
超伝導アンテナとフィルタのレーザトリミングによる特性改善
}

\author{
關谷 尚人 ${ }^{* 1, \dagger}$ 、小野 哲*1、中島 健介*2、齊藤 敦 ${ }^{* 1}$ 、平野 悟 ${ }^{* 1}$ 、大嶋 重利 ${ }^{* 1}$
}

\section{Improvement of Superconducting Antenna and Filter Properties using Laser Trimming}

\author{
Naoto SEKIYA $^{* 1, \uparrow}$, Satoshi ONO ${ }^{* 1}$, Kensuke NAKAJIMA ${ }^{* 2}$, Atsushi SAITO ${ }^{* 1}$, \\ Satoru HIRANO ${ }^{* 1}$ and Shigetoshi OHSHIMA ${ }^{* 1}$
}

\begin{abstract}
Synopsis: Improvements in superconducting device characteristics using laser-etching trimming is examined. A $\mathrm{KrF}$ excimer laser $(248 \mathrm{~nm})$ was used. As an example, improving the bandwidth of a superconducting patch antenna with gapcoupled resonators and that insertion loss of a 3-pole hairpin-type superconducting filter were studied. We found that laseretching trimming is quite useful for improving the antenna and filter properties; increasing the bandwidth and reducing return loss with the antenna, and reducing loss with the filter.
\end{abstract}

Keywords: superconductor, antenna, filter, trimming, laser, etching

\section{1. はじめに}

超伝導体はマイクロ波領域において常伝導金属に比べて 表面抵抗が二桁近く小さいという特徵をもつ。このことか ら超伝導体を用いたマイクロ波デバイスへの応用研究が盛 んに行われている。特に、フィルタ、アンテナ、位相器な ど受動デバイスの研究は盛んで、米国では超伝導フィルタ が実用化され、中国でもフィールド試験が始まっている。 しかし、これらマイクロ波デバイスを所望の特性を有する ように試作する技術はいまだ十分解決しているとはいえな い。例えば、フィルタでは最適なフィルタパターンを用い ても、使用する基板の誘電率、厚みがその設計に用いた值 とわずかでもずれていれば、フィルタ特性が大幅にずれて しまうからである。内田らは $\mathrm{MgO}$ 基板を使用した場合士 0.05 誘電率がずれると中心周波数が $0.5 \mathrm{MHz}$ ずれると報 告している ${ }^{1)}$ 。また、基板の厚多精度は更に厳しく、基板 厚 $0.5 \mathrm{~mm}$ で最適化されたフィルタの場合、2 $\mu \mathrm{m}$ の基板 厚のばらつきにより中心周波数は $0.5 \mathrm{MHz}$ ずれ、これを 制御することは難しい。以上のことから、デバイス作製後

Received October 24, 2005

${ }^{* 1}$ 山形大学工学部

厂992-8510 山形県米沢市城南 4-3-16

Faculty of Engineering, Yamagata University,

4-3-16, Jonan, Yonezawa, Yamagata 992-8510, Japan

*2 弘前大学理工学部

干036-8561 青森県弘前市文京町 3

Faculty of Engineering, Hirosaki University,

3, Bunkyouchou, Hirosaki, Aomori 036-8561, Japan

† E-mail: g02234@dipfr.dip.yz.yamagata-u.ac.jp
に周波数特性を調整する手法は必要不可欠である。フィル タの特性改善の方法としてトリミングとチューニングがあ り様々な方法が考案されている。サファイア板を用いフィ ルタ全体の共振器のキャパシタンスを変化させ中心周波数 や帯域幅を可変するチューニング方法 ${ }^{2) 31}$ 。サファイア ロッドとニッケルロッドを用いて個々の共振器のキャパシ タンスやインダクタンスを調整するトリミング方法 ${ }^{4)}$ 。し かし、デバイス作製後に直接デバイスパターンを加工する ことで特性改善する手法は少ない5)。そこで、我々はレー ザエッチングを用いデバイス作製後にトリミングを行う手 法について報告する。

本論文では、はじめに、ギャップ結合型共振器付き超伝 導アンテナ ${ }^{6)}$ を用いて、レーザエッチングの有効性を述べ る。また、レーザエッチングによるトリミングの 1 手法と して 3 段超伝導ヘアピンフィルタを用い、その有効性を検 討した。

\section{2. レーザエッチング装置}

レーザエッチングにはエキシマレーザ(浜松ホトニクス 製 C3470-XS)を用いた。封入ガスには KrF (248 nm)を使用 している。レーザエッチングはエキシマレーザによる極め て高いエネルギーパルス光を試料に照射しエネルギーを与 えることで試料の薄膜を離脱させ物理的にエッチングを行 う方法である。Fig. 1 にレーザエッチング装置の概略図を 示す。レーザ発振部で発振したエキシマレーザはマイクロ ステージ上の試料に照射される。発振するレーザのショッ 


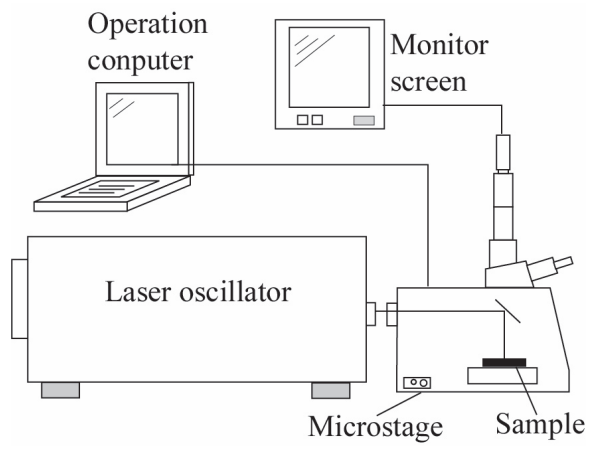

Fig. 1 Schematic of the laser-etching system.

卜数や試料の $\mathrm{X}-\mathrm{Y}$ 方向の移動はオペレーションコン ピュータにより制御される。マイクロステージ上の試料は ステージ上部の CCD カメラを通してモニター画面に表示 される。レーザによるエッチング状況はこのモニターを通 して確認できる。封入ガスの波長から原理的には $248 \mathrm{~nm}$ という微細加工が可能であるが、本装置では、可変アパー チャと呼ばれるレーザ照射領域を決定するスリットにより エッチング可能な幅は約 $1 \mu \mathrm{m}$ である。

エキシマレーザエッチング装置の利点は $1 \mu \mathrm{m}$ という 高精細なパターンをエッチング可能であるということであ る。一般的にパターン幅が $20 \mu \mathrm{m}$ 以下の微細パターンの エッチングには高価なクロムマスクが必要であるがそれを 必要としない。また、マスクを必要としないために、レジ ストを塗布する必要もないため大変簡便であることがわか る。さらに、大気中で加工可能であるという大きな利点も 持つ。

しかしながら、レーザを用いたエッチングのため、広範 囲を一度にエッチングするのには向かない。そこで、デバ イスのトリミングなどのデバイスの微調整という2 次的 エッチング方法としての使用が期待できる。

\section{3. ギャップ結合型共振器付き超伝導アンテナを 用いたレーザエッチングの検討}

\section{1 ギャップ結合型共振器付き超伝導アンテナ}

はじめに、ギャップ結合型共振器付き超伝導アンテナ (Gap-Coupled Resonators Antenna: GCRA)について述べる。 Fig. 2 に GCRA の概略図を示す。一般的な 1 素子パッチア ンテナの両側にパッチ型の共振器を配した構造をしてお り、左右の共振器のサイズをわずかにずらすことで共振周 波数をずらし帯域幅を向上させるアンテナである ${ }^{7)}$ 。Fig. 3 に 1 素子超伝導アンテナと超伝導 GCRA の電磁解析シ ミュレータによるリターンロス(R.L.)特性を示す。このア ンテナの特徴として帯域内に二つの共振をもたせることで 帯域幅を 1 素子アンテナより広げている。有効帯域幅を定 在波比 $\mathrm{SWR} \leqq 2$ とすると、リターンロスでは R.L. ミ

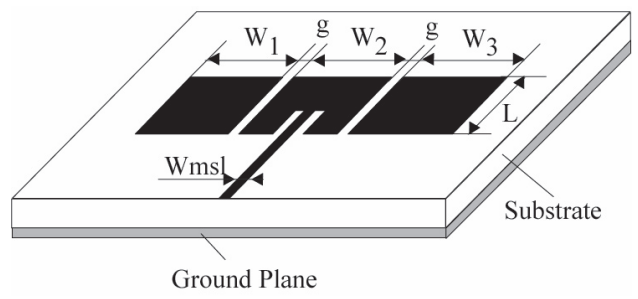

Fig. 2 Configuration of GCRA

Table 1 Overall dimensions of GCRA

\begin{tabular}{|c|c|}
\hline Parameters & Dimension[mm] \\
\hline $\mathrm{Wmsl}$ & 0.50 \\
\hline $\mathrm{W}_{1}$ & 3.55 \\
\hline $\mathrm{W}_{2}$ & 3.64 \\
\hline $\mathrm{W}_{3}$ & 3.46 \\
\hline $\mathrm{L}$ & 3.64 \\
\hline $\mathrm{g}$ & 0.35 \\
\hline
\end{tabular}

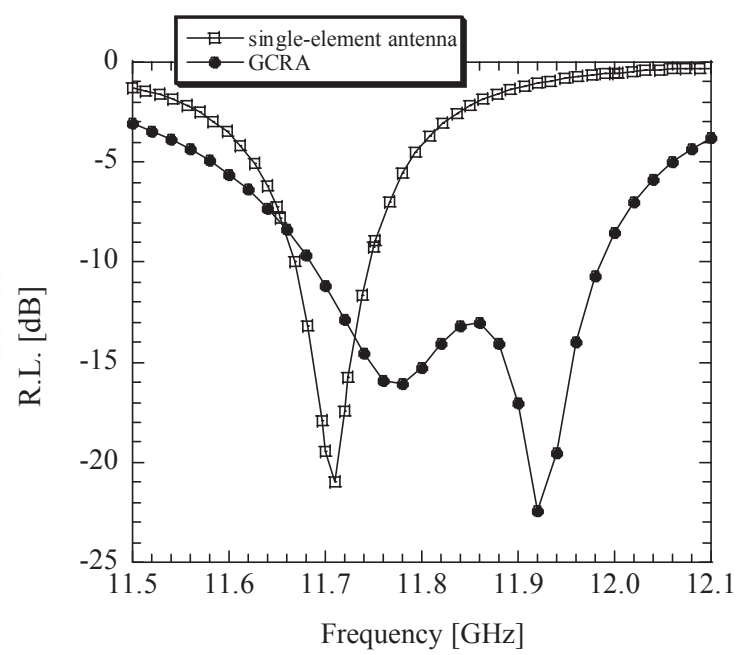

Fig. 3 Simulated return loss variation with a frequency of GCRA and a single element antenna.

-9.5 dB となり 1 素子に対して GCRA は約 2.5 倍帯域幅が 広がる。このときの、サイズを Table 1 に示す。基板には $\mathrm{r}-\mathrm{Al}_{2} \mathrm{O}_{3}$ を用いた。

\section{2 実験方法}

GCRA の特性は左右の共振器の幅 $\mathrm{W}_{1} 、 \mathrm{~W}_{3}$ と左右の共振 器と中央のメインパッチとの間のギャップ幅 $\mathrm{g}$ に大きく依 存する ${ }^{5)}$ 。そこで、Fig. 3 のギャップ部分をレーザエッチ ングで削っていくことで、ギャップ幅 $\mathrm{g}$ を広げる。同時に 左右の共振器の幅 $\mathrm{W}_{1} 、 \mathrm{~W}_{3}$ を狭くしていくことでアンテ ナ特性が変化し特性を改善できるか実験的に検討を行っ た。レーザエッチングによる特性の変化を測定するため に、ギャップ幅 $\mathrm{g}=0.025 \mathrm{~mm}$ とし、Table 1 で得られた值 より $0.010 \mathrm{~mm}$ 小さくした。小さくなった $0.010 \mathrm{~mm}$ を左 右の共振器の幅 $\mathrm{W}_{1} 、 \mathrm{~W}_{3}$ に付加し、 $\mathrm{W}_{1}=3.560 \mathrm{~mm} 、 \mathrm{~W}_{3}$ $=3.470 \mathrm{~mm}$ とした。この部分をレーザエッチングで 0.010 
$\mathrm{mm}$ ずつ削っていき特性の変化を評価した。GCRA の試作 には $20 \times 20 \times 0.5 \mathrm{~mm}$ の $\mathrm{R}$ 面サファイア基板上に誘導 結合スパッタリング装置により成膜した膜厚 $300 \mathrm{~nm}$ の YBCO 薄膜を使用した。グランド面には金を使用した。 GCRA パターンはフォトリソグラフィとドライエッチン グを用いてパターニングを行った。冷却には GM 型冷凍 器を使用した。測定にはベクトルネットワークアナライ ザー(Wiltron 360)を用い、電波暗室内でアンテナのリター ンロス特性を測定し評価した。

\subsection{GCRsA 試作とレーザェッチング}

Fig. 4 にレーザエッチングにより各パラメータが変化し たときの GCRA のリターンロス特性を示す。測定温度は $30 \mathrm{~K}$ である。Fig. 4 より、レーザエッチングにより、低周 波側の共振はギャップ幅が広がったことで減少し改善され ている。また、左右の共振器のサイズ $\mathrm{W}_{1} 、 \mathrm{~W}_{3}$ が小さく なることで高周波側の共振周波数が高周波にシフトするこ とがわかる。ギャップを $0.010 \mathrm{~mm}$ 削りシミュレーション と同サイズになったとき（ $\mathrm{g}=0.035 \mathrm{~mm} 、 \mathrm{~W}_{1}=3.550$ $\left.\mathrm{mm} 、 \mathrm{~W}_{3}=3.460 \mathrm{~mm}\right)$ 設計どおりの特性を得られていない ことがわかる。これは $\mathrm{r}-\mathrm{Al}_{2} \mathrm{O}_{3}$ 基板を使用しておりシミュ レータでは $\mathrm{r}-\mathrm{Al}_{2} \mathrm{O}_{3}$ 基板のもつ異方性を考慮できないため だと考えられる。このことからさらにレーザエッチングに

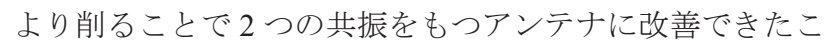
とを確認できた。しかし、エッチングによって左右の共振 器が小さくなったために、二つの共振間隔が広がってしま い有効帯域幅が狭くなっている。今後、 $\mathrm{g}=0.055 \mathrm{~mm} 、 \mathrm{~W}_{1}$ $=3.550 \mathrm{~mm} 、 \mathrm{~W}_{3}=3.460 \mathrm{~mm}$ で GCRA を試作することで 所望の特性のアンテナが得られるであろう。

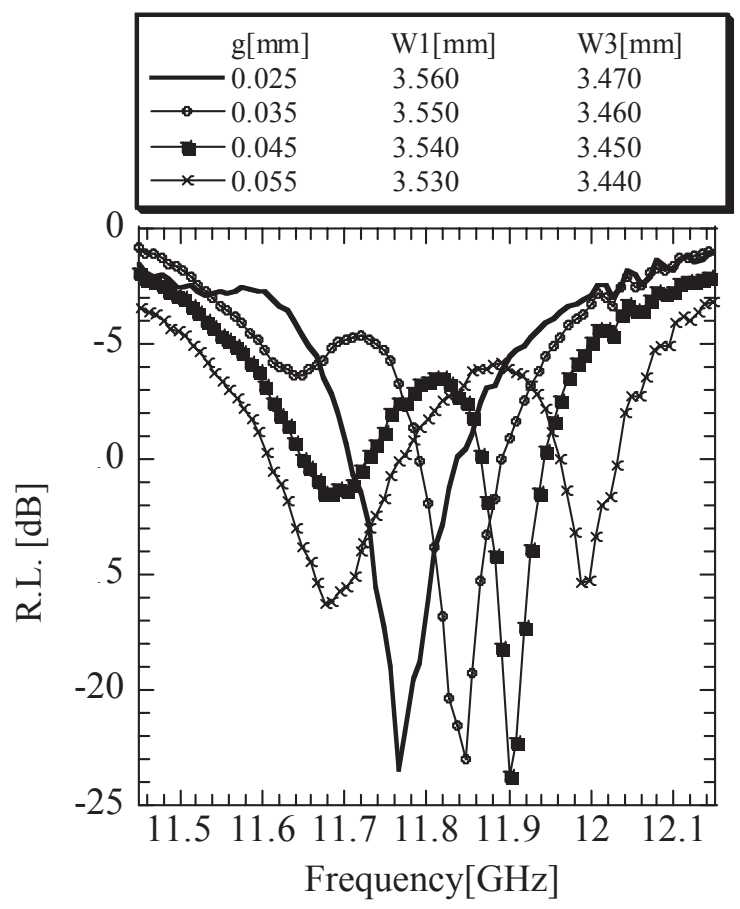

Fig. 4 The experimental variations of R.L. with frequency.
次に、Fig. 5 にレーザエッチングによって加工した ギャップ幅 $\mathrm{g} の 1000$ 倍の顕微鏡写真を示す。Fig. 5(a)はg $=0.025 \mathrm{~mm}$ から $0.010 \mathrm{~mm}$ エッチングを行った $\mathrm{g}=0.035$ $\mathrm{mm}$ のときの写真である。Fig. 5(b)は $\mathrm{g}=0.025 \mathrm{~mm}$ から $0.020 \mathrm{~mm}$ エッチングを行った $\mathrm{g}=0.045 \mathrm{~mm}$ のときの写真 である。(a)、(b)ともに上部がドライエッチングによるも のであり、下部がレーザエッチングによるものでる。エッ チング精度は Fig. 5 からわかるようにほぼ正確に 0.010 mm のエッチングができていることがわかる。また、ドラ イエッチングのカットの荒さに比ベレーザエッチングの カット面の方が平坦であることもわかる。しかし、下部の レーザエッチングでは、薄膜表面が変色してしまう。これ は、レーザ強度がガウス分布的であり、目的のエッチング 場所の周囲に弱いレーザが照射され表面がわずかにエッチ ングされたためだと思われる。この、表面の変色による影 響については 4.3 段チェビシェフ型へアピン共振器フィル タを用いたレーザエッチングの検討で議論する。

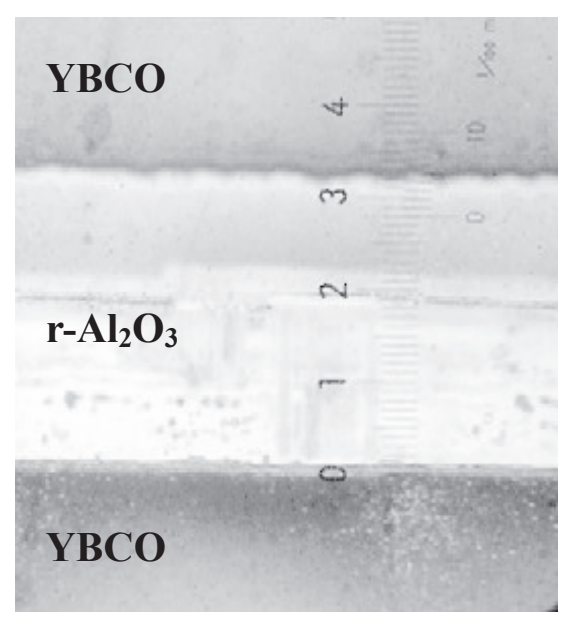

(a)

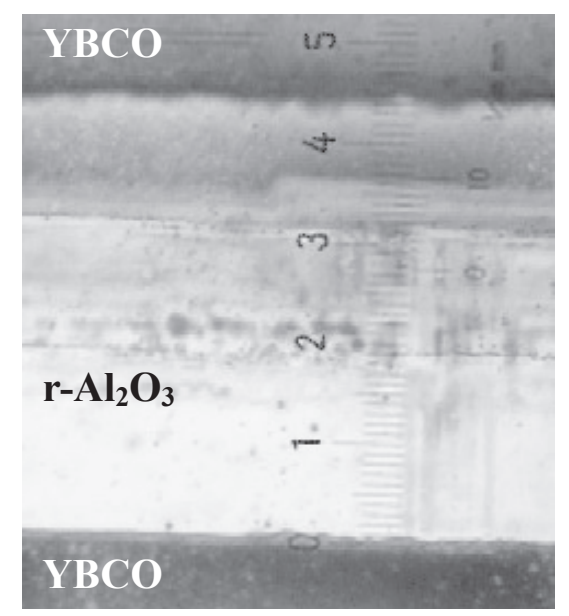

(b)

Fig. 5 (a) Scanning microscopy images of gap width $\mathrm{g}=0.035 \mathrm{~mm}$. (b) Scanning microscopy images of gap width $\mathrm{g}=0.045 \mathrm{~mm}$. 
以上より、レーザエッチングによるアンテナ特性のトリ ミングの有効性を示した。また、1枚のアンテナによりサ イズを変えることでデバイスの基礎特性の評価も可能であ ることから、使用する薄膜を減らすことも可能であり大変 有用である。さらに、シミュレーションなどで考慮できな いパラメータは実験でしか得ることができず、形状を変更 させながら 1 から試作プロセスを繰り返さなければならな い点を考慮するとレーザエッチングには大きなメリットが ある。

\section{3 段チェビシェフ型ヘアピン共振器フィルタを} 用いたレーザェッチングの検討

\section{1 実験方法}

Fig. 6 に今回試作した 3 段チェビシェフ型ヘアピン共振 器フィルタを示す。中心周波数が $2 \mathrm{GHz}$ になるように設 計を行った。フィルタにおけるレーザエッチングトリミ ングの有効性を確認するために、本実験では、特性の変化 が分かりやすいように 1 番目の共振器長だけを設計值より $0.030 \mathrm{~mm}$ 長くして試作を行い、この共振器をレーザエッ チングで $0.010 \mathrm{~mm}$ ずつ削ることで特性の変化をみながら 評価を行った。測定にはベクトルネットワークアナライ ザー(Agilent E8358)を用い、フィルタの評価は通過特性 (S21)の周波数依存性を用いた。フィルタの試作は基板を $25 \times 5 \times 0.5 \mathrm{~mm}$ の $\mathrm{R}$ 面サファイア基板を使用したこと 以外、上記 GCRA と同様の薄膜、膜厚、パターニング方 法である。

文献 1)をもとに誘電率が士 0.01 、基板厚が士 $0.005 \mathrm{~mm}$ 設計值よりずれていた場合の中心周波数のずれとそれを修 正するために必要な共振器の長さを計算した。その結果、 最大で中心周波数は土 $20 \mathrm{MHz}$ 設計值からずれ、それを 所望の設計值に修正するためには最大で士 $0.060 \mathrm{~mm}$ 共振 器長を修正しなければならない。このことから今回使用し

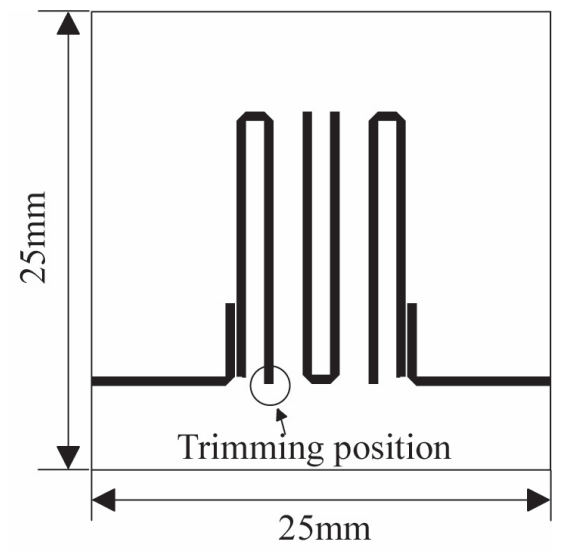

Fig. 6 Configuration of 3-pole chebyshev-type hairpin resonator filter with trimming position.
た+ $0.030 \mathrm{~mm}$ という值は前もつて共振器長を長く設計す るのに十分に可能性のある長さである。

\section{2 実験結果}

Fig. 7 (a)と(b)に今回試作した 3 段へアピン型フィルタの 通過特性 $\mathrm{S}_{21}$ の結果を示す。測定温度は $30 \mathrm{~K}$ である。通 過帯域内の損失が約 $3 \mathrm{~dB}$ 近くあるのは、グランド面に金 薄膜を用いたために、その損失があらわれているためであ る。グランド面に金薄膜を用いた場合、2-3 dB の損失が生 じることは、以前の論文で報告されている ${ }^{8)}$ 。Fig. 7 (a)よ りトリミングによるフィルタの帯域外スカート特性は大き く変化していないことがわかる。しかし、トリミングに よって帯域内の通過特性は大きく変化しており、帯域内の 通過特性の変化がフィルタ特性として大変重要である。そ

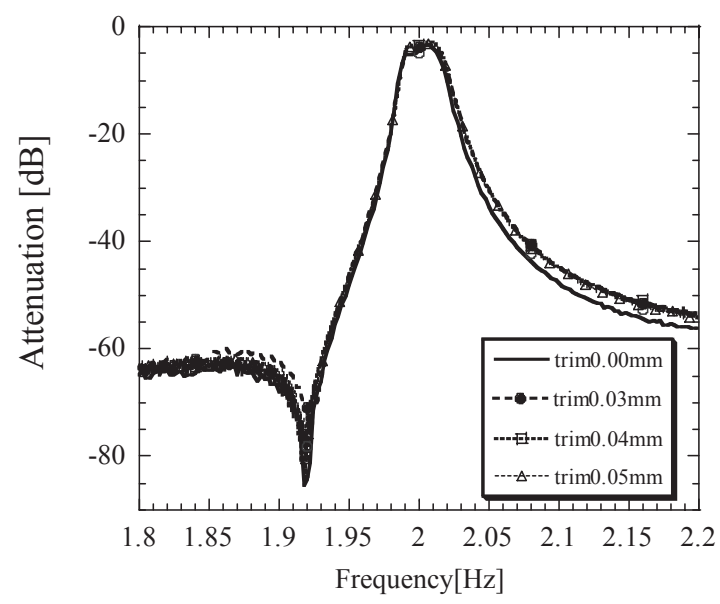

(a)

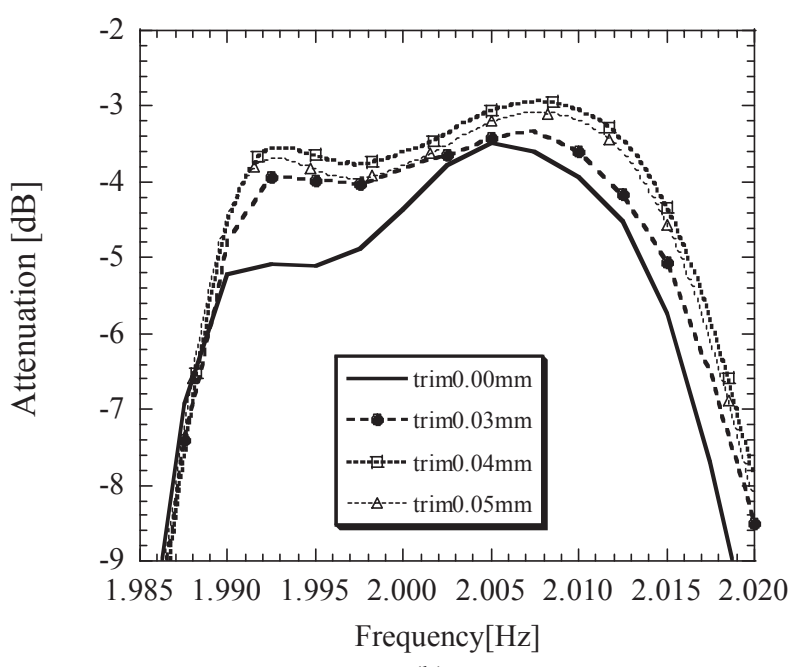

(b)

Fig. 7 Transmission characteristics $S_{21}$ of before and after trimming of various trim lengths.

(a) Frequency rage from $1.8 \mathrm{G} \mathrm{Hz}$ to $2.2 \mathrm{GHz}$, (b) Frequency rage from $1.985 \mathrm{GHz}$ to $2.020 \mathrm{GHz}$.

TEION KOGAKU (J. Cryo. Soc. Jpn.) Vol. 41 No. 2 (2006) 
こで、Fig. 7(b)に通過帯域内の拡大図を示す。trim $0.00 \mathrm{~mm}$ から $0.03 \mathrm{~mm}$ 削って設計值と同じサイズになったとき通 過特性が大きく改善されていることがわかる。次に、設計 值より共振器長をさらに削ることで特性が改善されるか エッチングを行った。trim $0.04 \mathrm{~mm}$ で通過特性は最大值と なった。trim $0.05 \mathrm{~mm}$ では最大值から減少したが trim 0.03 $\mathrm{mm}$ より全体として通過特性は向上した。この結果から、 設計值より短くすることで更に特性の改善が考えられるが trim $0.04 \mathrm{~mm}$ と trim $0.05 \mathrm{~mm}$ は通過特性が向上すると同時 にリップルが大きくなっていることがわかる。フィルタの 特性としては、帯域内の通過特性がより平坦になることが 望まれることから、フィルタ特性として最もよいのは trim $0.03 \mathrm{~mm}$ のときであり、すべての共振器長がそろったとき だと言える。

今回は 1 個の共振器長だけを長くしたが、すべての共振 器長がそれぞれずれていた場合には帯域内通過特性は大幅 に劣化すると考えられる。そこで、0.001 mm のオーダー で共振器サイズをそろえられれば大幅な通過特性の改善に つながると考えられる。

最後に、レーザエッチングによる薄膜表面の変色につい て検討を行った。Fig. 5 (a)より薄膜表面が変色している部 分は $0.005 \mathrm{~mm}$ 程度である。そのレーザエッチングによる 変色部分を超伝導薄膜の表面抵抗が劣化していると仮定 し、変色部分の表面抵抗值を変化させシミュレーションを 行った。その結果、銅を用いた場合、通過特性にほとんど 変化がなく、絶縁体を仮定した場合でも通過特性における リップルがわずかに変化しただけであった。この理由とし て、 $0.005 \mathrm{~mm}$ は一つの共振器の約 $0.18 \%$ の長さであり、 一つの共振器のわずかな変化では全体の特性に大きく影響 しないためだと考えられる。しかし、この検討では実際に 超伝導薄膜が劣化しているかについては正確に評価できな い。また、さらに高周波化が進めば、フィルタの共振器サ イズは縮小するため、0.005 mm の薄膜状態の重要性は増 加する。このことから、今後、加工前後の臨界温度や臨界 電流密度から薄膜表面の変色による超伝導特性への影響の 詳細な検討が必要である。

以上より、レーザエッチングによって共振器長を削るこ とで特性を改善できることを明らかにした。今後、一つの 共振器ではなくフィルタを構成するすべての共振器長をあ らかじめ長めに作っておき、レーザエッチングですべての 共振器長を調節することで所望の中心周波数をもつフィル タにトリミングできると考えられる。

\section{5. まとめ}

レーザエッチングによって広帯域ギャップ結合型共振器 付き超伝導アンテナ(GCRA)と 3 段チェビシェフ型へアピ ンフィルタのトリミングを行い、トリミング前後の特性を
比較した。GCRA では、ギャップ結合している左右の共 振器を $0.010 \mathrm{~mm}$ ずつ削ることでトリミングを行った。そ の結果リターンロス特性が改善でき、また、そのことに よって帯域幅の向上につながることを明らかにした。ま た、フィルタでは、共振器長を $0.010 \mathrm{~mm}$ ずつエッチング することでトリミングを行った。その結果、帯域内におけ る通過特性が向上し、リップルを減少できることを明らか にした。今後、他のトリミングと組み合わせることで、よ り所望の特性をもつアンテナやフィルタの試作が期待でき る。

\section{参 考 文 献}

1) T. Uchida, M. Suto, H. Mikami, M. Takeda, M. Kusunoki, A. Saito, M. Masashi, S. Ohshima, "Improvement of superconducting filter properties using sapphire rod trimming,” TEION KOGAKU 39 (2004) 18-25 (in Japanese) 内田 貴ら：「サファイアロッドトリミングによる超 伝導フィルタの特性改善」, 低温工学 39 (2004) 18-25

2) H. Fuke, Y. Terashima, F. Aiga, M. Yamazaki, H. Kayano, T. Hashimoto. "High- $\mathrm{T}_{\mathrm{c}}$ superconducting sharp skirt tunable filters," IEICE Trans. Electron. E85-C (2002) 704-707

3) F. Aiga, Y. Terashima, M. Yamazaki, H. Fuke, H. Kayano, R. Kato, T. Hashimoto. "Bandwidth tujable high- $\mathrm{T}_{\mathrm{c}}$ superconducting filter," Physica C 383 (2002) 43-47

4) F. Aita, N. Sekiya, S. Ono, A. Saito, S. Hirano, S. Ohshima, "Improvement of filter properties using sapphire and nickel rod trimmers," to be published in IEICE Trans. Electron. 2006

5) G. Tsuzuki, B. A. Willemsen, "Design of high performance planar bandpass filters," $18^{\text {th }}$ International Symposium on Superconductivity (2005) 140

6) N. Sekiya, A. Kubota, S. Hirano, A. Saito, S. Ohshima, "Broad-Band superconducting microstrip antenna using additional gap-couple resonators," IEICE Technical Report SCE2005-14 (2005) 11-16 (in Japanese).

關谷 尚人ら：「ギャップ結合型共振器を用いた広带 域 超伝導マイクロストリップアンテナの検討」, 信 学技報, SCE2005-14 (2005) 11-16

7) N. Sekiya, A. Kubota, S. Hirano, A. Saito, S. Ohshima, "Broad-Band superconducting microstrip antenna using additional gap-couple resonators," $18^{\text {th }}$ International Symposium on Superconductivity (2005) 142

8) K. Ehata, M. Kusunoki, S. Ohshima, "Design, fabrication, and characterization of patch antenna using superconducting thin film," Electronics and Communications in Japan, Part2, 82 (1999) 915923

關 谷 尚人昭和 52 年 9 月 23 日生. 平成 13 年山形大学工 学部電子情報工学科卒業. 平成 15 年年同大学院理工学研究科博士 前期課程(電子情報工学専攻)修了. 現在、同大学院理工学研究科博 士後期課程(システム情報工学専攻)在学中. 主に HTS デバイスの設 計・試作・評価に従事 
小野 哲 昭和 58 年 2 月 7 日生. 平成 17 年山形大学工学 部電気電子工学科卒業. 同年同大学院理工学研究科博士前期課程 (電気電子工学専攻)在学中. 現在、主に HTS フィルタの設計・試 作・評価に従事

中 島 健 介 昭和 31 年 12 月 20 日生. 昭和 54 年日本 大学理工学部卒業. サンケン電気(株)を経て昭和 56 年長岡技術 科学大学勤務. 大助手を経て平成 3 年東北大学電気通信研究所助 手. 平成 5 年同助教授. 平成 15 年弘前大学理工学部教授. 現在 に至る. 主として超伝導エレクトロニクスの研究に従事. 低温工 学協会, 応用物理学会, 電子情報通信学会, 応用磁学会会員, 日 本セラミックス協会. 工学博士.

齊 藤 敦昭和 47 年 1 月 1 日生. 平成 6 年長岡技術科学大 学電子機器工学科卒業. 平成 8 年同大学院博士前期課程(電気電子 工学専攻)修了. 平成 11 年同大学院博士後期課程(エネルギー・環境 工学専攻)修了. 同年同大学電気系助手. 平成 13 年通信総合研究所 (現情報通信研究機構) 関西先端研究センター専攻研究員. 平成 15 年山形大学工学部電気電子工学科助手. 一貫して超伝導薄膜及
びデバイスの研究に従事. 低温工学協会, 応用物理学会, 電子情報 通信学会. 博士 (工学).

平 野 悟昭和 38 年 12 月 31 日生. 昭和 61 年北海道大学 理学部物理学科卒業. 平成 12 年同大学院工学研究科博士後期課程 (システム情報工学専攻)修了. 平成 13 年(財) 国際超電導産業技術 研究センター 超電導工学研究所 主任研究員. 平成 16 年 11 月より 山形大学工学部電気電子工学科助教授. 主に超伝導エレクトロニク スの研究に従事. 米国物理学会, 電子情報通信学会会員. 工学博 士.

大 嶋重 利 昭和 24 年 6 月 13 日生. 昭和 48 年東北大学工 学部卒業. 昭和 53 年同大学院工学研究科博士後期課程(電気通信工 学)修了. 昭和 53 年東北大工学部に勤務. 昭和 64 年から山形大学 工学部に勤務し，現在に至る。主に，超伝導エレクトロニクス，特 にフィルタやアンテナなどのパッシブデバイスの開発や，表面抵抗 測定システムの開発等に従事. 低温工学協会, 応用物理学会, 電子 情報通信学会, 電気学会, 応用磁気学会会員. 工学博士 